102 Original Investigation / Özgün Araştırma

\title{
Prevalence of Intestinal Parasites in Hamsters and Rabbits in Some Pet Shops of Turkey
}

\author{
Petshoplardaki Hamster ve Tavşanlarda Bağırsak Parazitlerinin Yaygınlığı
}

\author{
Neslihan Sürsal', Sami Gökpinar², Kader Yildiz² \\ ${ }^{1}$ Ankara University, Faculty of Veterinary Medicine, Ankara, Turkey \\ ${ }^{2}$ Department of Parasitology, Kırıkkale University Faculty of Veterinary Science, Kırıkkale, Turkey
}

\begin{abstract}
Objective: In this study, we aimed to determine the parasite species carried by hamsters and rabbits purchased from some commercial pet shops in Turkey.

Methods: For this purpose, the fecal samples of clinically healthy Syrian hamsters, dwarf hamsters, and crossbred rabbits were collected from 22 pet shops randomly selected in Ankara and Kirikkale provinces, located in Central Anatolia Region of Turkey. The fecal samples were examined with centrifuge flotation technique using saturated salt solution.

Results: Parasitic infection rate was 57.5\% in dwarf hamsters, $54.9 \%$ in Syrian hamsters, and $56.3 \%$ in crossbreed rabbits. Trichurid eggs were the most prevalent parasite in the feces of Syrians hamsters (28.1\%). The other parasites of Syrian hamsters were as follows: Eimeria spp. oocysts (15.4\%) and the eggs of H. nana (11.2\%), Syphacia spp. (11\%). and Aspiculuris spp. (5.6\%). Only trichurid eggs were observed in the fecal samples of dwarf hamsters (51.5\%). Oocysts of Eimeria spp. (52.7\%) and the eggs of P. ambiguus (3.6\%) were detected in the feces of rabbits. Conclusion: Within the scope of this study, the detection of $H$. nana eggs, a zoonotic parasite, in the feces of Syrian hamster was quite remarkable for public health. (Turkiye Parazitol Derg 2014; 38: 102-5)
\end{abstract}

Key Words: Parasite, pet shop, rabbit, hamster, fecal examination

Received: 27.08.2013

Accepted: 27.01.2014

\section{ÖZET}

Amaç: Bu çalışmada petshoplarda satılan hamster ve tavşanlarda bulunan parazit türlerinin belirlenmesi amaçlanmıştır.

Yöntemler: Ankara ve Kırıkkale'de rastgele seçilen 22 petshopta bulunan klinik olarak sağlıklı görünümlü Syrian hamster, cüce hamster ve tavşanlardan dışkı örnekleri toplanmıştır. Dışkı örnekleri doymuş tuzlu su kullanılarak santrifüj flotasyon yöntemi ile incelenmiştir.

Bulgular: Cüce hamsterlerin \%57,5'inin, Syrian hamsterlerin \%54,9'unun, tavşanların ise \%56,3'ünün parazitlerle enfekte olduğu bulunmuştur. Dışkı incelemesi sonucunda Syrian hamsterlerde Trichurid tipte yumurta $(\% 28,1)$ en yaygın olarak saptanmıştır. Bunu sırasıyla Eimeria spp. oocysti $(\% 15,4)$, H.nana $(\% 11,2)$, Syphacia spp. (\%11) ve Aspiculuris spp. $(\% 5,6)$ yumurtası izlemiştir. Cüce hamsterlerde yanlızca trichurid tipte yumurta gözlenmiştir $(\% 51,5)$. Incelenen tavşan dışkılarında ise Eimeria spp. oocystleri $(\% 52,7)$ ve P.ambiguus yumurtaları $(\% 3,6)$ tespit edilmiştir.

Sonuç: Bu çalışmada Syrian hamsterlerin dışkısında H.nana yumurtasının tespiti halk sağlığı bakımından oldukça önemlidir. (Turkiye Parazitol Derg 2014; 38: 102-5)

Anahtar Sözcükler: Parazit, petshop, tavşan, hamster, dışkı muayenesi

Geliş Tarihi: 27.08.2013

Kabul Tarihi: 27.01.2014

Address for Correspondence / Yazışma Adresi: Dr. Kader Yıldız, Department of Parasitology, Kırıkkale University Faculty of Veterinary Science, Kirkkkale, Turkey. Phone: +90 3183573301 E-mail: kaderyildiz@hotmail.com DOI:10.5152/tpd.2014.3338

CCopyright 2014 Turkish Society for Parasitology - Available online at www.tparazitolderg.org

OTelif hakkı 2014 Türkiye Parazitoloji Derneği - Makale metnine www.tparazitolderg.org web sayfasından ulaşılabilir. 


\section{INTRODUCTION}

Rabbit and hamster began to be cared at home as a hobby as did other pet animals such as cat and dog. In Turkey, various pet mammals are cared at home by owners. Hamster and rabbit species are preferred by children due to easy care. Hamsters and rabbits may harbor some parasites. One of them, Eimeria spp., is an intracellular protozoon that infects intestinal epithelia of hosts, except Eimeria stiedae, which infects bile duct epithelia of rabbits. The life cycle of Eimeria spp. is direct. Oocysts are passed with host feces and infective for hosts after sporulation in the environment. Transmission is by fecal-oral route (1).

Syphacia and Aspiculuris spp. are morphologically similar nematodes belonging to the Oxyuroidea superfamily. These nematodes are common in the intestinal lumen of rodents. The life cycle of Syphacia and Aspiculuris spp. is direct. Aspiculuris spp. eggs are passed in the feces, unlike in Syphacia spp., the eggs of which are deposited on the perianal region of the host. Eggs are embryonated in the environment (Aspiculuris spp.) or on the perianal region (Syphacia spp.) (2). Infection by ingestion of infective eggs, and retroinfections may also occur in Syphacia spp. Passalurus ambiguus, the other member of the Oxyuroidea superfamily, is the common pinworm of rabbits. Adult parasites inhabiting the cecum and colon produce embryonated eggs, which are infective when passed (1).

Capillaria and Trichuris spp. are belonging to the Trichuroidea superfamily. Several Capillaria species occur in the gastrointestinal or urinary tracts of mice and rats. Trichuris species live in the cecum and colon of hosts. The life cycle of these nematodes is direct. Eggs are embryonated when passed, are oval and brown with a thick shell, and have bipolar plugs, called characteristic trichurid eggs (1).

Hymenolepis nana (Syn. Rodentolepis nana) is also known as the dwarf tapeworm of mice. It is a member of the family Hymenolepididae. The tapeworm occurs in the small intestines of rodents. $H$. nana is the only cestode species to be transmitted directly, since the eggs passed in the feces of the definitive host are infective to another definitive host. Indirect transmission also occurs in the $H$. nana life cycle (2). Infective larvae develop in some intermediate hosts as grain beetles, flour beetles, and fleas. The definitive host becomes infected by ingestion of the infected insects. Another way of infection is autoinfection (1).
There are only limited reports on parasites of pet shop rodents (3-6) and rabbits (7). To the authors' knowledge, any data was found parasitic diseases of pet rodents and rabbits in Turkey. We aimed to determine parasites species carried by hamsters and rabbits in some pet shops in Turkey.

\section{METHODS}

In this study, the fecal samples of clinically healthy Syrian hamsters (n: 71), dwarf hamsters ( $n: 33)$, and crossbred rabbits ( $n: 55)$ were collected from 22 different pet shops randomly selected in Ankara and Kirikkale, located in the Central Anatolia Region of Turkey between September 2009-March 2010. The fecal samples were taken from animals provided by different breeders. Each animal was put in separate cages, and the feces samples were taken from individual animals from their droppings. The feces samples were examined by centrifuge flotation technique using saturated salt solution in the Parasitology Laboratory of Kirikkale University Faculty of Veterinary Medicine by using light microscope (8).

\section{RESULTS}

Parasitic infection rate was $51.5 \%$ of dwarf hamsters (17/33), $54.9 \%$ of Syrian hamsters (39/71), and $56.3 \%$ of crossbred rabbits $(31 / 55)$. Table 1 shows the parasite species of the animals sampled from the different pet shops. Trichurid eggs were most prevalent in the feces of Syrians hamsters (28.1\%). The other parasites of Syrian hamsters were as follows: Eimeria spp. oocysts (15.4\%) and the eggs of Syphacia spp. (11\%), H. nana (11.2\%), and Aspiculuris spp. (5.6\%). Only trichurid eggs were observed in the fecal samples of dwarf hamsters (51.5\%). Oocysts of Eimeria spp. (52.7\%) and eggs of P. ambiguus (3.6\%) were detected in the feces of rabbits.

\section{DISCUSSION}

Parasites of laboratory animals are well known by scientists. Several reports are related to parasites of laboratory rodents (9-12). Although laboratory rodents maintain their life-controlled conditions in animal care units, sometimes these animals can be exposed to different parasitic diseases, some of which are infective for human. Similar to laboratory rodents, pet rodents harbor a lot of parasites species. However, there are only limited data related to parasites of rodents in pet shops (3-6). Dammann et al. (6) observed that more than $70 \%$ of the mice purchased from pet shops are positive in respect to endoparasites. The most prevalent parasitic infection was reported as Syphacia spp. in pet rodents (3-6). Also,

Table 1. Prevalence of parasite species in hamsters and rabbits examined with coprology

\begin{tabular}{|c|c|c|c|c|c|c|c|c|}
\hline \multicolumn{2}{|c|}{ Animal } & \multirow{2}{*}{$\begin{array}{l}\text { Infected } \\
\text { animal } \\
\text { number } \\
(\%)\end{array}$} & \multicolumn{6}{|c|}{ Parasite species } \\
\hline Species & $\mathrm{n}$ & & $\begin{array}{l}\text { Eimeria } \\
\text { spp. } \\
(\%)\end{array}$ & $\begin{array}{l}\text { H. nana } \\
(\%)\end{array}$ & $\begin{array}{c}\text { Trichurid } \\
\text { eggs } \\
\text { (\%) }\end{array}$ & $\begin{array}{c}\text { Syphacia } \\
\text { spp. } \\
(\%)\end{array}$ & $\begin{array}{l}\text { Aspiculuris } \\
\text { spp. } \\
\text { (\%) }\end{array}$ & $\begin{array}{c}\text { P. ambiguus } \\
(\%)\end{array}$ \\
\hline Syrian hamster & 71 & $\begin{array}{c}39 \\
(54.9 \%)\end{array}$ & $\begin{array}{c}11 \\
(15.4 \%)\end{array}$ & $\begin{array}{c}8 \\
(11.2 \%)\end{array}$ & $\begin{array}{c}20 \\
(28.1 \%)\end{array}$ & $\begin{array}{c}11 \\
(15.4 \%)\end{array}$ & $\begin{array}{c}4 \\
(5.6 \%) \\
\end{array}$ & - \\
\hline Dwarf hamster & 33 & $\begin{array}{c}17 \\
(51.5 \%) \\
\end{array}$ & - & - & $\begin{array}{c}17 \\
(51.5 \%) \\
\end{array}$ & - & - & - \\
\hline Crossbred rabbit & 55 & $\begin{array}{c}31 \\
(56.3 \%)\end{array}$ & $\begin{array}{c}29 \\
(52.7 \%)\end{array}$ & & & & & $\begin{array}{c}2 \\
(3.6 \%)\end{array}$ \\
\hline
\end{tabular}


A. tetraptera and $H$. nana were observed in rodents of pet shops (3-5). In our study, the parasitic infections were found at a similar rate (54.9\%-57.5\%) in hamsters and rabbits. The most prevalent parasite species was trichurid eggs and oocysts of Eimeria spp. in the feces of hamsters and rabbits, respectively.

Some parasites, such as Syphacia and Aspiculuris spp., possess direct life cycles (1). Additionally, due to having short prepatent periods, these parasites can transmit easily among rodents held in the same cage. In the present study, the eggs of Syphacia spp. and Aspiculuris spp. were detected in Syrian hamsters at 11\% and $5.6 \%$, respectively. Also, all animals that lived in the same cage were infected with Syphacia and Aspiculuris spp. Different parasite species were observed in the examined animals obtained from different breeders in this study. Moreover, the same animal species obtained from different breeders put together in same cage constitute a risk of infection transmission among animals.

The prevalence of $H$. nana in laboratory rodents was high. Also, this tapeworm has been reported in some pet shop rodents (3-5). Humans have been considered to be susceptible to $H$. nana (1). In fact, in some parts of the world, especially in tropical regions, human infection is prevalent, particularly in children (13, 14 ) and immunodeficient patients $(15,16)$. However, transmission of $H$. nana between human and mice is controversial $(17,18)$. Macnish et al. (17) suggested that rodent and human isolates of $H$. nana may be different and not cross-infective. On the other hand, some author claimed that humans can be infected with the rodent isolate of $H$. nana (18). In our study, the detection of eggs of $H$. nana in the feces of Syrian hamster was quite remarkable for public health, because these rodents are in close contact with children and can move freely on their desk and bed.

Eimeria species are also frequently observed both in pets (7) and in other domestic rabbits (19). Similarly, Eimeria spp. was the most important parasite of clinically healthy pet rabbits in our study. The primary mode of transmission for Eimeria spp. is a fecal-oral route (1). This indicates that the high prevalence of Eimeria species in pet rabbits, especially subclinical cases, may be a potential reservoir for coccidiosis for other rabbits in the same cage.

\section{CONCLUSION}

In conclusion, to the best of our knowledge, this is the first report to describe the prevalence of parasitic diseases of pet rodents purchased from pet shops in Turkey. Due to close contact with their pets, children are at higher risk of zoonotic diseases from animals. People who own these pets and pet shop workers have risk of infection with parasites, because attention can not paid to personal hygiene.

Ethics Committee Approval: Ethics committee approval was not received due to the retrospective nature of this study.

Peer-review: Externally peer-reviewed.

Author Contributions: Concept - K.Y.; Design - K.Y.; Supervision - K.Y., S.G.; Funding - K.Y.; Materials - K.Y., S.G.; Data Collection and/or Processing - N.S., S.G.; Analysis and/or Interpretation K.Y., S.G.; Literature Review - K.Y.; Writing - K.Y., N.S.

Conflict of Interest: No conflict of interest was declared by the authors.

Financial Disclosure: The authors declared that this study has received no financial support.

Etik Komite Onayı: Çalışmamızın retrospektif tasarımından dolayı etik komite onayı alınmamıştır.

Hakem değerlendirmesi: Dış bağımsız.

Yazar Katkıları: Fikir - K.Y.; Tasarım - K.Y.; Denetleme - K.Y., S.G.; Kaynaklar - K.Y.; Malzemeler - K.Y., S.G.; Veri toplanması ve/veya işlemesi - N.S., S.G.; Analiz ve/veya yorum - K.Y., S.G.; Literatür taraması - K.Y.; Yazıyı yazan - K.Y., N.S.

Çıkar Çatışması: Yazarlar herhangi bir çıkar çatışması bildirmemişlerdir.

Finansal Destek: Yazarlar bu çalışma için finansal destek almadıklarını beyan etmişlerdir.

\section{REFERENCES}

1. Beck W, Pantchev N. Praktische Parasitologie bei Heimtieren. Hannover: Schlütersche Verlagsgesellschaft; 2006.

2. Mitchell MA, Tully TN. Manual of Exotic Pet Practice. Saunders, Elsevier; 2009

3. Pinto RM, Gonçalves L, Gomes DC, Noronha D. Helminth fauna of the golden hamster Mesocricetus auratus in Brazil. Contemp Top Lab Anim Sci 2001; 40: 21-6.

4. Hasegawa $H$, Sato H, Iwakiri E, Ikeda Y, Une Y. Helminths collected from imported pet murids, with special reference to concomitant infection of the golden hamsters with three pinworm species of the genus Syphacia (Nematoda: Oxyuridae). J Parasitol 2008; 94: 752-4. [CrossRef]

5. Lv CC, Feng C, Qi M, Yang HY, Jian FC, Ning CS, Zhang LX. [Investigation on the prevalence of gastrointestinal parasites in pet hamsters]. Zhongguo Ji Sheng Chong Xue Yu Ji Sheng Chong Bing Za Zhi 2009; 27: 279-80.

6. Dammann P, Hilken G, Hueber B, Köhl W, Bappert MT, Mähler M. Infectious microorganisms in mice (Mus musculus) purchased from commercial pet shops in Germany. Lab Anim 2011; 45: 271-5. [CrossRef]

7. Lim JJ, Kim DH, Lee JJ, Kim DG, Kim SH, Min W, Chang HH, Rhee $\mathrm{MH}, \mathrm{Kim} \mathrm{S}$. Prevalence of Lawsonia intracellularis, Salmonella spp. and Eimeria spp. in healthy and diarrheic pet rabbits. J Vet Med Sci 2012; 74: 263-5. [CrossRef]

8. Zajac AM, Conboy GA. Veterinary clinical parasitology. Blackwell Publish; 2009.

9. Pritchett-Corning KR, Cosentino J, Clifford CB. Contemporary prevalence of infectious agents in laboratory mice and rats. Lab Anim 2009; 43: 165-173. [CrossRef]

10. Tanideh N, Sadjjadi SM, Mohammadzadeh T, Mehrabani D. Helminthic infections of laboratory animals in animal house of Shiraz University of Medical Sciences and the potential risks of zoonotic infections for researchers. Iran Red Crescent Medical J 2010; 12: 151-7.

11. Chen XM, Li X, Lin RQ, Deng JY, Fan WY, Yuan ZG, Liao M, Zhu XQ. Pinworm infection in laboratory mice in southern China. Lab Anim 2011; 45: 58-60. [CrossRef] 
12. Gudissa T, Mazengia H, Alemu1 S, Nigussie H. Prevalence of gastrointestinal parasites of laboratory animals at Ethiopian Health and Nutrition Research Institute (EHNRI), Addis Ababa. J Infect.Dis Immun 2011; 3: 1-5.

13. Ashtiani MT, Monajemzadeh M, Saghi B, Shams S, Mortazavi SH, Khaki S, Mohseni N, Kashi L, Nikmanesh B. Prevalence of intestinal parasites among children referred to Children's Medical Center during 18 years (1991-2008), Tehran, Iran. Ann Trop Med Parasitol 2011; 105: 507-12. [CrossRef]

14. Matthys B, Bobieva M, Karimova G, Mengliboeva Z, Jean-Richard V, Hoimnazarova M, Kurbonova M, Lohourignon LK, Utzinger J, Wyss K. Prevalence and risk factors of helminths and intestinal protozoa infections among children from primary schools in western Tajikistan. Parasit \&Vectors 2011; 4: 195. [CrossRef]
15. Olson PD, Yoder K, Fajardo LF, Marty AM, van de Pas S, Olivier C Relman DA. Lethal invasive cestodiasis in immunosuppressed patients. J Infect Dis 2003; 187: 1962-6. [CrossRef]

16. Zali MR, Mehr AJ, Rezaian M, Meamar AR, Vaziri S, Mohraz M. Prevalence of intestinal parasitic pathogens among HIV-positive individuals in Iran. Jpn J Infect Dis 2004; 57: 268-70.

17. Macnish MG, Morgan UM, Behnke JM, Thompson RC. Failure to infect laboratory rodent hosts with human isolates of Rodentolepis (Hymenoloepis) nana. J Helminthol 2002; 76: 37-43. [CrossRef]

18. Fan PC. Infectivity and development of the human strain of Hymenolepis nana in ICR mice. Southeast Asian J Trop Med Public Health 2005; 36: 97-102.

19. Jing F, Yin G, Liu X, Suo X, Qin Y. Large-scale survey of the prevalence of Eimeria infections in domestic rabbits in China. Parasitol Res 2012; 110: 1495-500. [CrossRef] 